\title{
PENERAPAN MODEL COOPERATIVE LEARNING TIPE STUDENT TEAMS ACHIEVEMENT DIVISION (STAD) BERBANTU MEDIA MONOPOLI DALAM PENINGKATAN AKTIVITAS BELAJAR AKUNTANSI SISWA KELAS X AKUNTANSI 2 SMK NEGERI 1 GODEAN TAHUN AJARAN 2011/2012
}

\author{
Oleh: \\ Erma Wulandari ${ }^{1}$ \\ Sukirno $^{2}$
}

\begin{abstract}
Abstrak
Penelitian ini bertujuan untuk mengetahui peningkatan Aktivitas Belajar melalui Penerapan Model Cooperative Learning Tipe Student Teams Achievement Division (STAD) pada Kompetensi Dasar Menyusun Laporan Rekonsiliasi Bank Kelas X Akuntansi 2 SMK Negeri 1 Godean Tahun Ajaran 2011/2012.

Penelitian ini merupakan penelitian tindakan kelas yang dilaksanakan selama 2 siklus. Subjek penelitian adalah siswa kelas X Akuntansi 2 SMK Negeri 1 Godean Tahun Ajaran 2011/2012 sebanyak 36 siswa. Pengumpulan data dilakukan dengan observasi partisipasi, dokumentasi dan wawancara. Analisis data dilakukan dengan data reduction, data display, dan verification.

Berdasarkan hasil penelitian dapat disimpulkan bahwa terdapat peningkatan Aktivitas Belajar Siswa kelas X Akuntansi 2 SMK Negeri 1 Godean Tahun Ajaran 2011/2012 melalui penerapan Model Cooperative Learning Tipe Student Teams Achievement Division pada Kompetensi Dasar Menyusun Laporan Rekonsiliasi Bank. Aktivitas belajar secara umum mengalami peningkatan pada siklus I dan siklus II. Sebelum menggunakan Model Cooperative Learning Tipe STAD Aktivitas Belajar Siswa hanya 39,31\%, kemudian pada siklus I sebesar $67,43 \%$ dan menjadi $88,06 \%$ pada siklus II. Indikator Aktivitas Belajar khususnya siswa yang memperhatikan apa yang disampaikan guru mengalami peningkatan dari $68,06 \%$ menjadi $94,44 \%$, siswa yang bertanya dan menyampaikan pendapat pada saat kegiatan belajar atau diskusi mengalami peningkatan dari $53,47 \%$ menjadi $81,94 \%$, siswa yang bekerja sama dengan teman satu tim mengalami peningkatan dari $66,67 \%$ menjadi $88,19 \%$, siswa yang membuat perencanaan dan pembagian tugas tim mengalami peningkatan dari $67,36 \%$ menjadi $87,50 \%$, siswa yang bertanggung jawab terhadap tugas yang telah ditetapkan dalam tim mengalami peningkatan dari $70,83 \%$ menjadi $86,81 \%$, siswa yang mendiskusikan masalah yang dihadapi dalam kegiatan belajar mengajar mengalami peningkatan dari $74,31 \%$ menjadi $90,97 \%$, siswa yang bertukar pendapat antar teman dalam tim mengalami peningkatan dari $68,75 \%$ menjadi $84,72 \%$, siswa yang memiliki kepedulian terhadap kesulitan sesama anggota tim mengalami peningkatan dari 68,06\% menjadi $86,11 \%$, siswa yang mengambil keputusan dari pertimbangan anggota mengalami peningkatan dari $69,44 \%$ menjadi $86,11 \%$, serta siswa yang mengerjakan kuis dengan kemampuan sendiri mengalami peningkatan dari $67,36 \%$ menjadi $93,75 \%$.
\end{abstract}

\footnotetext{
${ }^{1}$ Alumni Program Studi Pendidikan Akuntansi UNY

${ }^{2}$ Dosen Jurusan Pendidikan Akuntansi UNY
} 
Kata Kunci: Cooperative Learning, Student Teams Achievement Division, Aktivitas Belajar Akuntansi, SMK Negeri 1 Godean

\section{A. Pendahuluan}

\section{Latar Belakang Masalah}

Pendidikan merupakan ujung tombak bagi pembangunan peradaban. Sumber daya manusia yang unggul akan mengantarkan bangsa menjadi maju dan kompetitif di tengah arus globalisasi, namun Indonesia masih mengalami hambatan dalam menciptakan kualitas pendidikan yang baik. Salah satu masalah yang dihadapi dalam dunia pendidikan saat ini yaitu masih lemahnya proses pembelajaran (Apriliana Rejeki, 2010). Proses pembelajaran yang berhasil apabila selama kegiatan belajar mengajar siswa menunjukkan Aktivitas Belajar yang tinggi dan terlihat secara aktif baik fisik maupun mental.

Guru dalam menyampaikan pelajaran akuntansi dituntut memilih metode yang dapat melatih siswa belajar mandiri dan lebih optimal. Sementara itu Yanda Nur (2011) memberikan fenomena yang berbeda bahwa hampir semua guru dalam mengajar menggunakan metode ceramah. Model pembelajaran ceramah memang tidak bisa dihilangkan, tetapi guru dituntut untuk mengembangkan kreativitasnya dalam memilih dan menggunakan model pembelajaran yang relatif banyak melibatkan keaktifan siswa dan menciptakan inovasi sehingga pembelajaran berlangsung menyenangkan. Salah satu model pembelajaran yang melibatkan peran siswa secara aktif dalam kegiatan belajar mengajar adalah model pembelajaran kooperatif (Sadam Hasan, 2011). Mushlihin al-Hafizh (2011) memberikan penjelasan bahwa model pembelajaran kooperatif merupakan salah satu model pembelajaran yang banyak digunakan untuk mewujudkan kegiatan pembelajaran yang berpusat pada peserta didik (student oriented), terutama untuk mengatasi permasalahan dalam proses pembelajaran.

Slavin (2010: 143) mengungkapkan bahwa salah satu model pembelajaran kooperatif yang paling sederhana adalah Tipe Student Teams Achievement Division (STAD) dan merupakan model yang paling baik untuk permulaan bagi para guru yang baru menggunakan pendekatan kooperatif. Isjoni (2010: 74) menyatakan pembelajaran kooperatif tipe STAD merupakan salah satu tipe kooperatif yang menekankan pembelajaran pada adanya aktivitas dan interaksi diantara siswa untuk saling memotivasi dan saling membantu dalam menguasai materi pelajaran guna mencapai prestasi yang maksimal. Penerapan model pembelajaran Cooperative Learning Tipe STAD perlu didukung oleh media pembelajaran yang dapat 
membantu peserta didik dalam membangkitkan minat dan motivasi siswa yang selanjutnya siswa akan melakukan Aktivitas Belajar.

Sharan dan rekanannya (dalam Slavin, 2010: 105) menemukan pengaruh positif dari STAD terhadap sikap-sikap etnik baik pada etnik Timur Tengah maupun Yahudi Eropa pada sekolah-sekolah Israel. Selanjutnya Suci Rohmawati (2011) membuktikan dalam penelitiannya melalui Penggunaan Model Pembelajaran Kooperatif Tipe STAD dengan hasil yang ditunjukkan adanya peningkatan persentase ketuntasan hasil belajar Akuntansi siswa kelas X Akuntansi 3 SMK N 1 Wonosari pada setiap siklus.

Berdasarkan prasurvey yang dilakukan oleh peneliti pada tanggal 30 November 2011, diperoleh data bahwa sebagian besar guru akuntansi SMK Negeri 1 Godean masih dominan menggunakan metode ceramah ketika pembelajaran. Terdapat variasi latihan yang digunakan, namun hal tersebut dirasakan belum bisa memfasilitasi cara belajar siswa untuk lebih aktif dan berprestasi. Dari 3 kelas X Akuntansi yang ada di SMK Negeri 1 Godean, Aktivitas Belajar siswa dalam kelas X Akuntansi 2 masih belum optimal dilihat dari sikap siswa yang pasif dan kurang berpartisipasi dalam pembelajaran akuntansi.

Aktivitas siswa pada kelas X Akuntansi 2 cenderung hanya duduk, diam dan mendengarkan. Siswa dalam proses pembelajaran bertindak sebagai objek pembelajaran, kurangnya aktivitas bertanya maupun berpendapat membuat pembelajaran menjadi monoton. Terkadang siswa lebih senang melakukan aktivitas lain, seperti diskusi sendiri dengan teman lainya dan saling bertukar benda yang tidak berhubungan dengan jalannya proses pembelajaran. Hal tersebut dicerminkan dengan 39,31\% siswa melakukan aktivitas belajar dari keseluruhan siswa di kelas X Akuntansi 2 sebanyak 36 siswa. (Berdasarkan hasil observasi 10 Februari 2012).

Melalui Model Cooperative Learning Tipe Student Teams Achievement Division (STAD) Berbantu Media Monopoli peneliti berupaya untuk meningkatkan Aktivitas Belajar siswa dalam pembelajaran akuntansi. Berdasarkan pada beberapa permasalahan yang ada, maka penelitian ini bertujuan untuk mengetahui Penerapan Model Cooperative Learning Tipe Student Teams Achievement Division (STAD) Berbantu Media Monopoli dalam Meningkatkan Aktivitas Belajar Akuntansi Siswa Kelas X Akuntansi 2 SMK Negeri 1 Godean Tahun Ajaran 2011/2012. 


\section{Kajian Pustaka}

a. Kajian Teori

1) Aktivitas Belajar pada Kompetensi Dasar Menyusun Laporan Rekonsiliasi Bank

Sriyono (2012) menjelaskan bahwa Aktivitas Belajar pada Kompetensi Dasar Menyusun Laporan Rekonsiliasi Bank diartikan sebagai kegiatan yang dilakukan siswa dalam proses belajar mengajar pada Kompetensi Dasar Menyusun Laporan Rekonsiliasi Bank baik secara fisik maupun mental yang akan menumbuhkan Aktivitas Belajar yang optimal dan dapat menciptakan lingkungan yang kondusif.

Menurut Paul D. Dierich (dalam Oemar Hamalik, 2005: 172-173), klasifikasi Aktivitas Belajar siswa dapat dibagi menjadi 8 kelompok, yaitu:

a) Kegiatan-kegiatan visual: Membaca, melihat gambar-gambar, mengamati eksperimen, demonstrasi, pameran, mengamati orang lain bekerja atau bermain.

b) Kegiatan-kegiatan lisan (oral): Mengemukakan suatu fakta atau prinsip, menghubungkan suatu kejadian, mengajukan suatu pertanyaan, memberi saran, mengemukakan pendapat, wawancara, diskusi, dan interupsi.

c) Kegiatan-kegiatan mendengarkan: Mendengarkan penyajian bahan, mendengarkan percakapan atau diskusi kelompok, mendengarkan suatu permainan, mendengarkan radio.

d) Kegiatan-kegiatan menulis: Menulis cerita, menulis laporan, memeriksa karangan, bahan-bahan kopi, membuat rangkuman, mengerjakan tes, dan mengisikan angket.

e) Kegiatan-kegiatan menggambar: Menggambar, membuat grafik, chart, diagram peta, dan pola.

f) Kegiatan-kegiatan metrik: Melakukan percobaan, memilih alat-alat, melaksanakan pameran, membuat model, menyelenggarakan permainan, menari dan berkebun.

g) Kegiatan-kegiatan mental: Merenungkan, mengingatkan, memecahkan masalah, menganalisa faktor-faktor, melihat hubungan-hubungan, dan membuat keputusan.

h) Kegiatan-kegiatan emosional: Minat, membedakan, berani, tenang, dan lain-lain.

Berdasarkan klasifikasi di atas, Aktivitas Belajar Siswa pada Kompetensi Dasar Menyusun Laporan Rekonsiliasi Bank dalam penelitian ini dapat dilihat dari 10 aspek, yaitu: memperhatikan apa yang disampaikan guru, bertanya dan menyampaikan pendapat pada saat kegiatan belajar atau diskusi, bekerja sama dengan teman satu tim, membuat perencanaan dan pembagian tugas tim, bertanggung jawab terhadap tugas yang telah ditetapkan dalam tim, mendiskusikan masalah yang dihadapi dalam kegiatan belajar mengajar, bertukar pendapat antar teman dalam tim, memiliki kepedulian terhadap kesulitan sesama anggota tim, mengambil keputusan dari pertimbangan anggota, dan mengerjakan kuis dengan kemampuan sendiri. 
2) Model Cooperative Learning Tipe Student Teams Achievement Division (STAD) Berbantu Media Monopoli

Model Cooperative Learning Tipe Student Teams Achievement Division (STAD) Berbantu Media Monopoli diartikan sebagai model pembelajaran kooperatif yang mendorong siswa untuk saling membantu, memotivasi, serta menguasai keterampilan yang diberikan oleh guru. Pembelajaran dengan menggunakan sistem pengelompokan/tim kecil, yaitu antara empat sampai enam orang yang mempunyai latar belakang kemampuan akademik, jenis kelamin, ras atau suku yang heterogen (Wina Sanjaya, 2009: 242). Komponen dari STAD terdiri dari presentasi kelas, tim, kuis, skor kemajuan individual, dan rekognisi tim (Slavin, 2010: 143-146).

Penggunaan bantuan media monopoli untuk memberikan variasi dalam mengatasi sikap pasif siswa. Merujuk dari Arief S. Sadiman dkk (2011: 7) media digunakan untuk menyalurkan pesan dari guru kepada siswa sehingga dapat merangsang pikiran, perasaan, perhatian dan minat serta perhatian siswa sedemikian rupa sehingga proses belajar terjadi. Monopoli adalah satu permainan papan dan pemain berlomba untuk mengumpulkan kekayaan melalui satu pelaksanaan sistem permainan dengan memasukan petak pertanyaan yang akan dijawab oleh peserta permainan. Adapun kelengkapan dari model STAD berbantu permainan monopoli adalah papan permainan, dadu, lembar pertanyaan, dan lembar hasil permainan (Dodo Suwanda: 2008).

\section{b. Penelitian yang Relevan}

Penelitian yang relevan dalam penelitian ini merupakan penelitian terdahulu yang telah dilakukan sebelum penelitian ini. Penelitian terdahulu berfungsi sebagai pendukung untuk melakukan penelitian. Adapun penelitian terdahulu yang telah dilakukan adalah:

1) Ummu Rubiyatun (2011) dalam penelitiannya yang berjudul Implementasi Model Cooperative Learning Tipe Student Teams Achievement Division (STAD) Untuk Meningkatkan Aktivitas Belajar Siswa Kelas X AK 3 SMK Batik Perbaik Purworejo, hasilnya menunjukkan bahwa setelah diterapkan model pembelajaran Cooperative Learning Tipe STAD, aktivitas belajar siswa mengalami peningkatan pada siklus I dan II. Terdapat respon positif sebesar $94 \%$ dan respon negatif sebesar $6 \%$ siswa kelas X AK 3 terhadap implementasi Model Cooperative Learning Tipe STAD. Persamaan penelitian ini dengan penelitian relevan adalah pada tujuan penelitian, yaitu Aktivitas Belajar Siswa 
dan penggunaan Model Cooperative Learning Tipe STAD. Perbedaannya pada penggunaan media pembelajaran, subjek dan tempat penelitian.

2) Apri Nur Aini Esofa (2011) dalam penelitiannya yang berjudul Penerapan Model Cooperative Learning Tipe Student Team Achievement Division (STAD) Untuk Meningkatkan Keaktifan Siswa pada Kompetensi Membukukan Ayat Jurnal Penutup dan Membuat Neraca Saldo Setelah Penutupan Siswa Kelas X AK 2 SMK Muhammadiyah 2 Klaten Utara, disimpulkan bahwa keaktifan siswa secara umum mengalami peningkatan pada siklus I dan II. Sebelum menggunakan model Cooperative Learning Tipe STAD keaktifan siswa hanya 32,26\%, kemudian pada siklus I keaktifan siswa meningkat sebesar 59,19\% menjadi 80,32\% pada siklus II. Persamaan penelitian ini dengan penelitian relevan adalah dalam penggunaan model pembelajaran. Perbedaannya yaitu subjek dan tempat penelitian.

3) Suci Rohmawati (2011) dalam penelitiannya yang berjudul Peningkatan Hasil Belajar Akuntansi Pada Kompetensi Mengelola Dana Kas Kecil Melalui Penggunaan Model Pembelajaran Kooperatif Tipe Student Teams Achievement Divisions Siswa Kelas X Akuntansi 3 SMK Negeri 1 Wonosari, hasilnya menunjukkan adanya peningkatan persentase ketuntasan hasil belajar Akuntansi siswa kelas X Akuntansi 3 SMK N 1 Wonosari pada setiap siklus. Pada siklus I persentase ketuntasan belajar siswa sebesar 68,57\%. Pada siklus II persentase ketuntasan belajar siswa mencapai 97,14\%. Penelitian ini memiliki kesamaan dengan penelitian relevan yakni pada penggunaan model pembelajaran. Perbedaan terletak pada pengukurannya, pada penelitian yang relevan mengukur hasil belajar siswa sedangkan pada penelitian ini mengukur Aktivitas Belajar Siswa. Perbedaan lainnya yaitu subjek dan tempat penelitian.

4) Dian Alimatussholikha HS (2008) dalam penelitiannya yang berjudul Permainan Monopoli dan Ular Tangga Sebagai Media Latihan Soal Fisika Pokok Bahasan Gaya Kelas VIII Di MTsN Yogyakarta I, menggunakan teknik analisis data uji korelasi dengan rumus korelasi product moment diteruskan dengan analisis jalur dengan menggunakan rumus path. Hasil penelitian menunjukkan bahwa model permainan monopoli dan ular tangga dalam pembelajaran fisika dapat digunakan untuk meningkatkan ketertarikan dan minat belajar fisika. Prestasi belajar fisika siswa meningkat dengan digunakannya media permainan monopoli dan ular tangga. Penelitian ini memiliki kesamaan dengan penelitian relevan pada penggunaan media pembelajaran 
monopoli. Perbedaannya adalah pada penggunaan model pembelajaran dan pengukurannya. Pada penelitian yang relevan mengukur prestasi dan minat belajar siswa sedangkan pada penelitian ini mengukur Aktivitas Belajar Siswa. Perbedaan lainnya yaitu subjek dan tempat penelitian.

\section{c. Kerangka Berpikir}

Proses pembelajaran mata diklat akuntansi di kelas X Akuntansi 2 SMK Negeri 1 Godean masih bersifat konvensional. Guru masih menggunakan metode ceramah dalam melakukan proses pembelajaran. Guru lebih sering berperan aktif di dalam kelas ketika menyampaikan materi sehingga menyebabkan siswa menjadi pasif dan merasa bosan untuk mengikuti pelajaran yang disampaikan oleh guru. Proses pembelajaran akuntansi di kelas X Akuntansi 2 masih terdapat beberapa siswa yang aktivitas belajarnya belum optimal yang dibuktikan dari siswa lebih asyik mengobrol sendiri dengan temannya ketika guru sedang menyampaikan materi, selain itu siswa jarang bertanya atau berpendapat pada saat proses pembelajaran berlangsung atau pada saat diskusi. Guru dalam melihat situasi yang demikian, perlu melakukan pemecahan masalah yaitu guru harus mampu menciptakan suasana belajar yang optimal dengan mengimplentasikan berbagai model pembelajaran yang berpusat pada siswa. Aktivitas siswa dalam pembelajaran merupakan hal yang perlu diperhatikan agar siswa mampu mengkonstruksi pengetahuan sendiri, sedangkan guru hanya berperan sebagai fasilitator.

Menyikapi situasi ini, salah satu upaya yang digunakan dalam pembelajaran adalah pengembangan pembelajaran yang menekankan interaksi sosial siswa di kelas. Model Cooperative Learning Tipe Student Teams Achievement Division (STAD) merupakan salah satu strategi yang melibatkan interaksi siswa karena pembelajarannya didasarkan atas kerja sama kelompok dimana masing-masing individu memiliki tanggung jawab yang sama dalam mencapai tujuan kelompok. Penggunaaan media pembelajaran dapat membangkitkan minat dan motivasi siswa yang selanjutnya siswa akan melakukan aktivitas belajar. Media pembelajaran yang dirancang secara baik dapat mendukung proses belajar siswa dalam pembelajaran. 


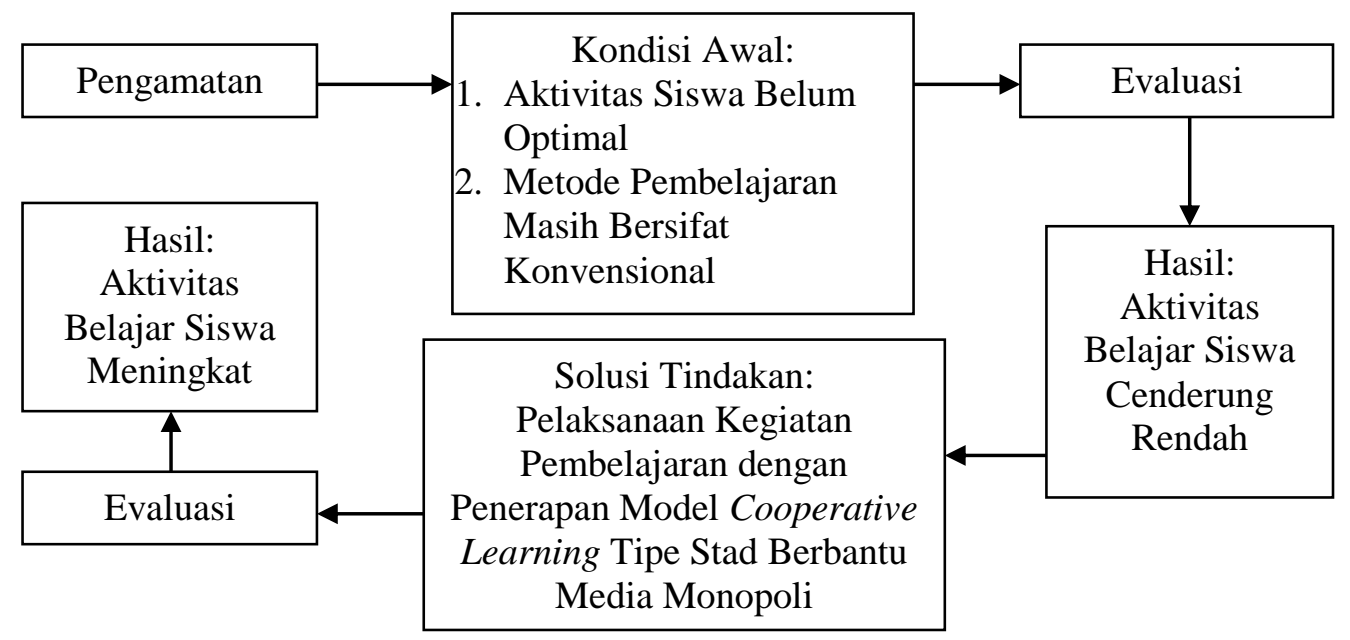

Gambar 1. Skema Kerangka Berpikir Penerapan Model Cooperative Learning Tipe STAD Berbantu Media Monopoli

\section{B. Metode Penelitian}

\section{Jenis Penelitian}

Penelitian ini merupakan penelitian tindakan kelas yang dilakukan secara kolaboratif dan partisipatif, artinya peneliti tidak melakukan penelitian sendiri, namun berkolaborasi atau bekerja sama dengan guru akuntansi di SMK Negeri 1 Godean. Secara partisipatif bersama-sama dengan mitra, peneliti akan melaksanakan penelitian ini langkah demi langkah. Wina Sanjaya (2011: 44) menyatakan "Penelitian tindakan kelas (PTK) adalah proses pengkajian masalah pembelajaran di dalam kelas melalui refleksi diri dalam upaya untuk memecahkan masalah tersebut dengan cara melakukan berbagai tindakan yang terencana dalam situasi nyata serta menganalisis setiap pengaruh dari perlakuan tersebut". Desain tindakan yang digunakan dalam penelitian ini adalah model Kemmis \& Taggart.

\section{Subjek dan Objek Penelitian}

Penelitian menggunakan subjek penelitian pada siswa kelas X SMK Negeri 1 Godean. Peneliti melakukan penelitian pada salah satu kelas X Akuntansi yaitu kelas X Akuntansi 2 yang terdiri dari 36 siswa. Peneliti memilih kelas tersebut karena masih terdapat siswa yang aktivitasnya belum optimal sehingga hasil belajarnya masih kurang maksimal. Objek penelitian adalah pelaksanaan pembelajaran akuntansi melalui Penerapan Model Cooperative Learning Tipe Student Teams Achievement Division (STAD) Berbantu Media 
Monopoli dalam Peningkatan Aktivitas Belajar Akuntansi Siswa Kelas X Akuntansi 2 SMK Negeri 1 Godean.

\section{Teknik Pengumpulan Data}

\section{a. Observasi partisipasi}

Observasi partisipatif adalah observasi yang dilakukan apabila observer ikut serta dalam kegiatan atau situasi yang dilakukan oleh observant (Wina Sanjaya, 2011: 92). Observasi partisipasi dilakukan untuk mengetahui unjuk Aktivitas Belajar siswa selama pengembangan tindakan dalam pembelajaran Akuntansi serta kondisi kelas saat pembelajaran dengan menggunakan model Cooperative Learning Tipe STAD.

Observasi dilaksanakan selama proses pembelajaran berlangsung di kelas oleh peneliti dan dibantu dengan 2 orang observer dari rekan peneliti yang memiliki latar belakang yang sama dengan peneliti. Hal ini dilakukan agar observasi siswa lebih fokus. Terdapat 3 orang observer di dalam kelas dan dari 36 siswa dibentuk 9 kelompok yang setiap kelompok terdiri dari 4 siswa, sehingga 1 observer akan bertanggung jawab mengamati 3 kelompok atau 12 siswa. Peneliti dan rekan akan berdiskusi untuk menyamakan pemahaman agar tujuan observasi tercapai. Observasi menggunakan lembar penilaian aktivitas siswa yang terdapat indikator-indikator Aktivitas Belajar, berikut juga dengan pedoman penilaian agar dapat membantu dalam mengamati aktivitas belajar siswa untuk pemberian skor kepada setiap siswa.

Penilaian terhadap aspek yang diobservasi dijabarkan ke dalam bentuk skala atau kriteria tertentu dan setiap alternatif penilaian ditentukan dengan nomor yang disebut dengan numerical rating scale (Wina Sanjaya, 2011: 95). Penilaian dilakukan dengan cara memberikan skor sesuai dengan kriteria penilaian, selanjutnya peneliti dan rekan melakukan penghitungan terhadap skor tiap-tiap siswa dan hasilnya digunakan untuk keperluan analisis.

b. Dokumentasi

Dokumentasi digunakan untuk memperoleh data mengenai jumlah siswa sebagai dasar untuk menentukan jumlah serta anggota-anggota kelompok dalam Cooperative Learning Tipe STAD. Dokumentasi juga berupa data mengenai gambaran profil sekolah, silabus, Rencana Pelaksanaan Pembelajaran (RPP), Lembar Observasi Aktivitas, catatan lapangan, hasil wawancara, dan foto selama kegiatan di sekolah. 
c. Wawancara

Wawancara dalam penelitian ini dilakukan kepada guru Akuntansi dan beberapa siswa kelas $\mathrm{X}$ Akuntansi 2 sebelum dan sesudah kegiatan pembelajaran dengan diimplementasikannya model Cooperative Learning Tipe STAD. Hasil wawancara digunakan untuk memperkuat hasil observasi selama kegiatan pembelajaran akuntansi dengan menerapkan model Cooperative Learning Tipe STAD.

Patton dalam Molleong (2002) yang dinyatakan dalam Sugiyono (2009: 322) menggolongkan enam jenis pertanyaan yang saling berkaitan yaitu:

1) Pertanyaan yang berkaitan dengan pengalaman

2) Pertanyaan yang berkaitan dengan pendapat

3) Pertanyaan yang berkaitan dengan perasaan

4) Pertanyaan tentang pengetahuan

5) Pertanyaan yang berkenaan dengan indera

6) Pertanyaan berkaitan dengan latar belakang atau demografi

Dari enam hal tersebut di atas digunakan sebagai pedoman membuat kisi-kisi wawancara.

\section{Instrumen Penelitian}

\section{a. Lembar Observasi}

Lembar observasi adalah lembar yang berisi indikator-indikator Aktivitas Belajar Siswa dan digunakan dalam pengamatan di kelas. Adapun komponen yang diamati seperti tabel di berikut ini:

Tabel 1. Indikator Penilaian Persentase Aktivitas Belajar Siswa dalam Penerapan Model Cooperative Learning Tipe STAD Berbantu Media Monopoli.

\begin{tabular}{|c|c|c|c|c|c|c|}
\hline \multirow{2}{*}{ No } & \multirow{2}{*}{ Indikator } & \multicolumn{5}{|c|}{ Skor } \\
\hline & & 0 & 1 & 2 & 3 & 4 \\
\hline 1 & Memperhatikan apa yang disampaikan guru & & & & & \\
\hline 2 & $\begin{array}{l}\text { Bertanya dan menyampaikan pendapat pada saat } \\
\text { kegiatan belajar atau diskusi }\end{array}$ & & & & & \\
\hline 3 & Bekerja sama dengan teman satu tim & & & & & \\
\hline 4 & Membuat perencanaan dan pembagian tugas tim & & & & & \\
\hline 5 & $\begin{array}{l}\text { Bertanggung jawab terhadap tugas yang telah } \\
\text { ditetapkan dalam tim }\end{array}$ & & & & & \\
\hline 6 & $\begin{array}{l}\text { Mendiskusikan masalah yang dihadapi dalam kegiatan } \\
\text { belajar mengajar }\end{array}$ & & & & & \\
\hline 7 & Bertukar pendapat antar teman dalam tim & & & & & \\
\hline 8 & $\begin{array}{l}\text { Memiliki kepedulian terhadap kesulitan sesama } \\
\text { anggota tim }\end{array}$ & & & & & \\
\hline 9 & Mengambil keputusan dari pertimbangan anggota & & & & & \\
\hline
\end{tabular}


Jurnal Pendidikan Akuntansi Indonesia, Vol. X, No. 1, Tahun 2012

Erma Wulandari \& Sukirno

Halaman 135 - 161

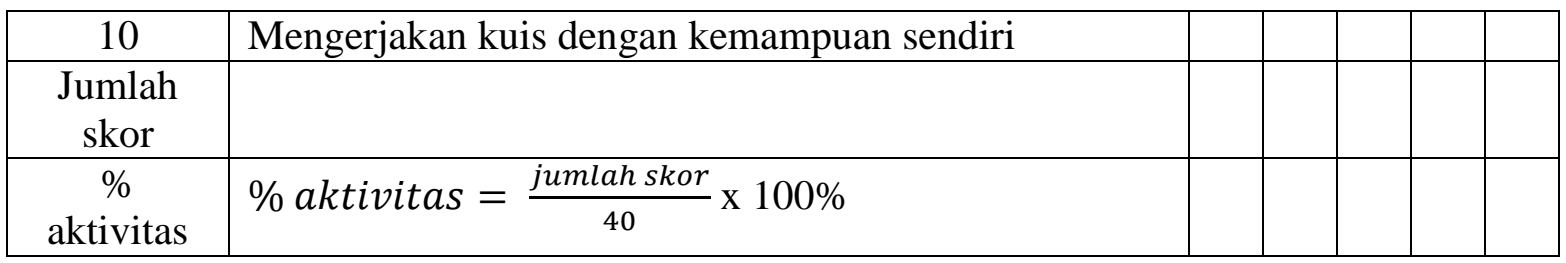

Dimodifikasi dari: Apri Nur Esofa (2011) dan Ummu Rubiyatun (2011)

Kriteria penilaian instrumen Aktifitas Belajar Siswa.
0 = Tidak aktif
$1=$ Kurang aktif
2 = Cukup aktif
$3=$ Aktif
$4=$ Sangat aktif 
Jurnal Pendidikan Akuntansi Indonesia, Vol. X, No. 1, Tahun 2012

Erma Wulandari \& Sukirno

Halaman 135 - 161

Tabel 2. Pedoman Penilaian Aktivitas Belajar Siswa dalam Penerapan Model Cooperative Learning Tipe STAD Berbantu Media Monopoli

\begin{tabular}{|c|c|c|c|c|c|c|}
\hline \multirow[b]{2}{*}{ No } & \multirow[b]{2}{*}{ Indikator } & \multicolumn{5}{|c|}{ Skor } \\
\hline & & $\begin{array}{l}\text { Tidak Aktif } \\
(0)\end{array}$ & $\begin{array}{l}\text { Kurang Aktif } \\
\text { (1) }\end{array}$ & $\begin{array}{l}\text { Cukup Aktif } \\
\text { (2) }\end{array}$ & $\begin{array}{l}\text { Aktif } \\
(3)\end{array}$ & $\begin{array}{l}\text { Sangat Aktif } \\
\text { (4) }\end{array}$ \\
\hline 1 & $\begin{array}{l}\text { Memperhatikan apa } \\
\text { yang disampaikan } \\
\text { guru }\end{array}$ & $\begin{array}{l}\text { Tidak pernah } \\
\text { memperhatikan sama } \\
\text { sekali }\end{array}$ & $\begin{array}{l}\text { Kurang } \\
\text { memperhatikan }\end{array}$ & $\begin{array}{l}\text { Kadang-kadang } \\
\text { memperhatikan }\end{array}$ & $\begin{array}{l}\text { Sering } \\
\text { memperhatikan }\end{array}$ & $\begin{array}{l}\text { Selalu } \\
\text { memperhatikan } \\
\text { dengan baik }\end{array}$ \\
\hline 2 & $\begin{array}{l}\text { Bertanya dan } \\
\text { menyampaikan } \\
\text { pendapat pada saat } \\
\text { kegiatan belajar atau } \\
\text { diskusi }\end{array}$ & $\begin{array}{l}\text { Tidak pernah } \\
\text { bertanya atau } \\
\text { menyampaikan } \\
\text { pendapat }\end{array}$ & $\begin{array}{l}\text { Bertanya atau } \\
\text { menyampaikan } \\
\text { pendapat yang } \\
\text { tidak sesuai } \\
\text { dengan materi }\end{array}$ & $\begin{array}{l}\text { Bertanya atau } \\
\text { menyampaikan } \\
\text { pendapat yang } \\
\text { kurang sesuai } \\
\text { dengan materi }\end{array}$ & $\begin{array}{l}\text { Sering bertanya atau } \\
\text { menyampaikan } \\
\text { pendapat yang sesuai } \\
\text { dengan materi }\end{array}$ & $\begin{array}{l}\text { Selalu bertanya } \\
\text { atau } \\
\text { menyampaikan } \\
\text { pendapat yang } \\
\text { sesuai dengan } \\
\text { materi }\end{array}$ \\
\hline 3 & $\begin{array}{l}\text { Bekerja sama dengan } \\
\text { teman satu tim }\end{array}$ & Tidak ada kerja sama & $\begin{array}{l}\text { Kurang bekerja } \\
\text { sama }\end{array}$ & $\begin{array}{l}\text { Kadang-kadang } \\
\text { bekerja sama }\end{array}$ & Sering bekerja sama & $\begin{array}{l}\text { Selalu bekerja } \\
\text { sama }\end{array}$ \\
\hline 4 & $\begin{array}{l}\text { Membuat perencanaan } \\
\text { dan pembagian tugas } \\
\text { tim }\end{array}$ & $\begin{array}{l}\text { Tidak ada } \\
\text { perencanaan dan } \\
\text { pembagian tugas }\end{array}$ & $\begin{array}{l}\text { Kurang dalam } \\
\text { perencanaan dan } \\
\text { pembagian tugas }\end{array}$ & $\begin{array}{l}\text { Kadang-kadang ada } \\
\text { perencanaan dan } \\
\text { pembagian tugas }\end{array}$ & $\begin{array}{l}\text { Sudah ada } \\
\text { perencanaan dan } \\
\text { pembagian tugas }\end{array}$ & $\begin{array}{l}\text { Perencanaan dan } \\
\text { pembagian tugas } \\
\text { secara sistematis }\end{array}$ \\
\hline 5 & $\begin{array}{l}\text { Bertanggung jawab } \\
\text { terhadap tugas yang } \\
\text { telah ditetapkan dalam } \\
\text { tim }\end{array}$ & $\begin{array}{l}\text { Tidak bertanggung } \\
\text { jawab terhadap tugas } \\
\text { tim }\end{array}$ & $\begin{array}{l}\text { Kurang } \\
\text { bertanggung } \\
\text { jawab terhadap } \\
\text { tugas tim }\end{array}$ & $\begin{array}{l}\text { Kadang-kadang } \\
\text { bertanggung jawab } \\
\text { terhadap tugas tim }\end{array}$ & $\begin{array}{l}\text { Sudah bertanggung } \\
\text { jawab terhadap tugas } \\
\text { tim }\end{array}$ & $\begin{array}{l}\text { Bertanggung jawab } \\
\text { penuh terhadap } \\
\text { tugas tim }\end{array}$ \\
\hline 6 & $\begin{array}{l}\text { Mendiskusikan } \\
\text { masalah yang dihadapi } \\
\text { dalam kegiatan belajar } \\
\text { mengajar }\end{array}$ & $\begin{array}{l}\text { Tidak pernah } \\
\text { berdiskusi }\end{array}$ & $\begin{array}{l}\text { Kurang dalam } \\
\text { berdiskusi }\end{array}$ & $\begin{array}{l}\text { Kadang-kadang } \\
\text { terlibat dalam } \\
\text { berdiskusi }\end{array}$ & $\begin{array}{l}\text { Sering terlibat dalam } \\
\text { berdiskusi }\end{array}$ & $\begin{array}{l}\text { Selalu aktif terlibat } \\
\text { dalam berdiskusi }\end{array}$ \\
\hline 7 & $\begin{array}{l}\text { Bertukar pendapat } \\
\text { antar teman dalam tim }\end{array}$ & $\begin{array}{l}\text { Tidak pernah } \\
\text { bertukar pendapat } \\
\text { dengan teman }\end{array}$ & $\begin{array}{l}\text { Kurang bertukar } \\
\text { bertukar pendapat } \\
\text { dengan teman }\end{array}$ & $\begin{array}{l}\text { Kadang-kadang } \\
\text { bertukar pendapat } \\
\text { dengan teman }\end{array}$ & $\begin{array}{l}\text { Sering bertukar } \\
\text { pendapat dengan } \\
\text { teman }\end{array}$ & $\begin{array}{l}\text { Selalu aktif dalam } \\
\text { tukar pendapat } \\
\text { dengan teman }\end{array}$ \\
\hline
\end{tabular}


Jurnal Pendidikan Akuntansi Indonesia, Vol. X, No. 1, Tahun 2012

Erma Wulandari \& Sukirno

Halaman $135-161$

\begin{tabular}{|c|l|l|l|l|l|l|}
\hline 8 & $\begin{array}{l}\text { Memiliki kepedulian } \\
\text { terhadap kesulitan } \\
\text { sesama anggota tim }\end{array}$ & $\begin{array}{l}\text { Tidak pernah } \\
\text { membantu kesulitan } \\
\text { sesama anggota }\end{array}$ & $\begin{array}{l}\text { Jarang membantu } \\
\text { kesulitan sesama } \\
\text { anggota }\end{array}$ & $\begin{array}{l}\text { Kadang-kadang } \\
\text { membantu kesulitan } \\
\text { sesama anggota }\end{array}$ & $\begin{array}{l}\text { Sering membantu } \\
\text { kesulitan sesama } \\
\text { anggota }\end{array}$ & $\begin{array}{l}\text { Selalu membantu } \\
\text { kesulitan sesama } \\
\text { anggota }\end{array}$ \\
\hline \multirow{8}{*}{9} & $\begin{array}{l}\text { Mengambil keputusan } \\
\text { dari pertimbangan } \\
\text { anggota }\end{array}$ & $\begin{array}{l}\text { Tidak pernah } \\
\text { mempertimbang-kan } \\
\text { kontribusi anggota }\end{array}$ & $\begin{array}{l}\text { Jarang } \\
\text { mempertimbang- } \\
\text { kan kontribusi } \\
\text { anggota }\end{array}$ & $\begin{array}{l}\text { Kadang-kadang } \\
\text { mempertimbang- } \\
\text { kan kontribusi } \\
\text { anggota }\end{array}$ & $\begin{array}{l}\text { Sering } \\
\text { mempertimbang- } \\
\text { kan kontribusi } \\
\text { anggota }\end{array}$ & $\begin{array}{l}\text { Selalu mempertimbang- } \\
\text { kan kontribusi anggota }\end{array}$ \\
\hline 10 & $\begin{array}{l}\text { Mengerjakan kuis } \\
\text { dengan kemampuan } \\
\text { sendiri }\end{array}$ & $\begin{array}{l}\text { Mencontek } \\
\text { pekerjaan teman }\end{array}$ & $\begin{array}{l}\text { Jarang } \\
\text { mengerjakan kuis } \\
\text { secara mandiri }\end{array}$ & $\begin{array}{l}\text { Kadang-kadang } \\
\text { ragu mengerjakan } \\
\text { kuis secara } \\
\text { mandiri }\end{array}$ & $\begin{array}{l}\text { Mengerjakan kuis } \\
\text { secara mandiri }\end{array}$ & $\begin{array}{l}\text { Lancar mengerjakan kuis } \\
\text { secara mandiri sebelum } \\
\text { waktu yang ditentukan }\end{array}$ \\
\hline
\end{tabular}

\section{b. Pedoman Wawancara}

Kisi-kisi atau pedoman wawancara guru dan siswa adalah sebagai berikut:

Tabel 3. Kisi- Kisi Wawancara Guru dan Siswa

\begin{tabular}{|c|c|c|}
\hline Sumber & Deskripsi Wawancara & No.item \\
\hline \multirow{6}{*}{$\begin{array}{l}\text { Guru } \\
\text { Akuntansi }\end{array}$} & 1. Penerapan model Cooperative Learning Tipe STAD Berbantu Media Monopoli. & 1 \\
\hline & 2. Perasaan guru terhadap model Cooperative Learning Tipe STAD Berbantu Media Monopoli. & 2 \\
\hline & 3. Ketercapaian tujuan pembelajaran akuntansi & 3 \\
\hline & 4. Manfaat penerapan model Cooperative Learning Tipe STAD Berbantu Media Monopoli. & 4 \\
\hline & 5. Hambatan dalam penerapan model Cooperative Learning Tipe STAD Berbantu Media Monopoli. & 5 \\
\hline & $\begin{array}{l}\text { 6. Solusi dalam mengatasi hambatan pelaksanaan pembelajaran dengan model Cooperative Learning Tipe } \\
\text { STAD Berbantu Media Monopoli. }\end{array}$ & 6 \\
\hline \multirow[t]{4}{*}{ Siswa } & 1. Penerapan model Cooperative Learning Tipe STAD Berbantu Media Monopoli. & 1 \\
\hline & 2. Perasaan siswa terhadap model Cooperative Learning Tipe STAD Berbantu Media Monopoli. & 2 \\
\hline & 3. Manfaat penerapan model Cooperative Learning Tipe STAD Berbantu Media Monopoli. & 3 \\
\hline & 4. Hambatan penerapan model Cooperative Learning Tipe STAD Berbantu Media Monopoli. & 4 \\
\hline
\end{tabular}


Jurnal Pendidikan Akuntansi Indonesia, Vol. X, No. 1, Tahun 2012

Erma Wulandari \& Sukirno

Halaman 135 - 161 


\section{c. Catatan Lapangan}

Catatan lapangan merupakan catatan yang berisi kesan dan penafsiran peneliti dalam bentuk naratif-deskriptif selama penerapan model Cooperative Learning Tipe STAD Berbantu Media Monopoli.

\section{Teknik Analisis Data}

\section{a. Analisis Data Kuantitatif}

Analisis data kuantitatif ini menganalisis data Aktivitas Belajar Siswa dalam tim, dilakukan dengan langkah-langkah sebagai berikut:

1) Memberikan kriteria pemberian skor terhadap masing-masing diskriptor pada setiap aspek Aktivitas yang diamati.

2) Menjumlahkan skor untuk masing-masing aspek Aktivitas yang diamati

3) Menghitung skor Aktivitas pada setiap aspek yang diamati dengan rumus:

$$
\%=\frac{\text { skor hasil aktivitas siswa }}{\text { Skor maksimum }} \times 100 \%
$$

\section{b. Analisis Data Kualitatif}

(Sugiyono, 2009:144)

Menurut Sugiyono (2009:338-345) teknis analisis data dilakukan melalui tiga tahap yang dilakukan dalam tiga komponen berurutan yaitu:

1) Data reduction atau reduksi data: merangkum memilih hal-hal pokok, memfokuskan pada hal-hal penting, dicari tema dan polanya dan membuang yang tidak perlu

2) Data display atau penyajian data: penyajian data dalam bentuk diagram, tabel, grafik, pie chart, dan sejenisnya.

3) Verification: langkah terakhir ini merupakan suatu kesimpulan yang dapat ditarik oleh peneliti dari masalah dan rumusan masalah yang disajikan.

\section{Indikator Keberhasilan}

Pembelajaran dikatakan berhasil dan berkualitas apabila seluruhnya atau setidaktidaknya sebagian besar (75\%) peserta didik terlibat secara aktif, baik fisik, mental maupun sosial dalam proses pembelajaran, di samping menunjukkan kegairahan belajar yang tinggi, semangat belajar yang besar, dan rasa percaya diri sendiri (E.Mulyasa, 2006:256). Indikator keberhasilan dalam penelitian ini adalah meningkatnya aktivitas belajar yang dicapai oleh siswa selama proses pembelajaran berlangsung dengan diterapkannya Model Cooperative 
Learning Tipe STAD Berbantu Media Monopoli pada kelas X Akuntansi 2 dari siklus I ke siklus II. Hal ini dapat mempengaruhi suasana pembelajaran akuntansi di kelas X Akuntansi 2 SMK 1 Negeri Godean dari yang kondusif menjadi lebih kondusif yang dibuktikan dengan sekurang-kurangnya aktivitas belajar siswa dapat mencapai $75 \%$.

\section{Hasil Penelitian dan Pembahasan}

\section{Hasil Penelitian}

\section{a. Kegiatan Pra-Tindakan}

1) Diskusi tentang Permasalahan dalam Pembelajaran Akuntansi

Peneliti melakukan diskusi dengan guru kolabolator pada tanggal 30 November 2011 untuk membahas permasalahan yang dihadapi oleh guru dalam pembelajaran. Wawancara dilanjutnya kepada beberapa siswa yang telah ditentukan sebelumnya sebagai perwakilan yang memiliki kemampuan akademik tinggi, sedang dan rendah. Dari data yang dikumpulkan, dapat dianalisis bahwa siswa kurang berpartisipasi dalam pembelajaran Akuntansi, Aktivitas siswa dan pemanfaatan belajar kelompok belum optimal. Kurangnya inovasi model pembelajaran dan pembelajaran yang bersifat konvensional yakni ceramah menyebabkan kurangnya interaksi dalam pembelajaran.

2) Observasi Awal

Observasi awal dilakukan untuk mengamati Aktivitas Belajar Siswa dalam pembelajaran di kelas dan memperkuat hasil wawancara. Berdasarkan observasi awal pada tanggal 10 Februari 2012, peneliti berhasil mengidentifikasi permasalahan pembelajaran pada kelas X Akuntansi 2 yaitu masih didominasi metode ceramah dan penugasan sehingga siswa kurang aktif dalam pembelajaran. Hal tersebut di cerminkan dengan 39,31\% siswa melakukan Aktivitas Belajar dari keseluruhan siswa di kelas X Akuntansi 2 sebanyak 36 siswa. Berikut adalah rincian Aktivitas Belajar Siswa pada pembelajaran konvensional.

Tabel 4. Aktivitas Belajar Siswa pada Pembelajaran Konvensional

\begin{tabular}{|c|l|c|}
\hline No & \multicolumn{1}{|c|}{ Indikator } & Persentase \\
\hline 1 & Memperhatikan apa yang disampaikan guru & $54,86 \%$ \\
\hline 2 & Bertanya pada saat kegiatan belajar atau diskusi & $35,42 \%$ \\
\hline 3 & Bekerja sama dengan teman satu tim & $36,81 \%$ \\
\hline 4 & Membuat perencanaan dan pembagian tugas tim & $30,56 \%$ \\
\hline 5 & Bertanggung jawab terhadap tugas yang telah ditetapkan dalam tim & $21,53 \%$ \\
\hline 6 & $\begin{array}{l}\text { Mendiskusikan masalah yang dihadapi dalam kegiatan belajar } \\
\text { mengajar }\end{array}$ & $50,00 \%$ \\
\hline
\end{tabular}




\begin{tabular}{|c|l|c|}
\hline 7 & Bertukar pendapat antar teman dalam tim & $43,06 \%$ \\
\hline 8 & Memiliki kepedulian terhadap kesulitan sesama anggota tim & $36,81 \%$ \\
\hline 9 & Mengambil keputusan dari pertimbangan anggota & $31,94 \%$ \\
\hline 10 & Mengerjakan kuis dengan kemampuan sendiri & $52,08 \%$ \\
\hline \multicolumn{2}{|c|}{ Rata - rata Aktivitas Belajar Siswa } & $39,31 \%$ \\
\hline
\end{tabular}

(Sumber: Data primer yang diolah)

\section{b. Perencanaan Penerapan STAD}

1) Menetapkan Upaya Peningkatkan Aktivitas Belajar Siswa dalam Pembelajaran Akuntansi Upaya dalam peningkatan Aktivitas Belajar Akuntansi Siswa kelas X Akuntansi 2 adalah dengan menggunakan Model Pembelajaran Cooperative Learning Tipe STAD Berbantu Media Monopoli pada Standar Kompetensi Memproses Dokumen Kas di Bank Kompetensi Dasar Menyusun Laporan Rekonsiliasi Bank. Pembentukan tim dilakukan secara heterogen dilihat dari kemampuan siswa berdasarkan nilai ulangan terakhir. Penentuan skor dasar dipilih dengan melakukan pre-test karena akan mencerminkan skor dasar dalam Kompetensi Dasar Menyusun Laporan Rekonsiliasi Bank dan dapat mengetahui pemahaman siswa sebelum tindakan.

2) Penyusunan Rencana Tindakan

Rancangan ini disesuaikan dengan komponen pada Tipe STAD sebagai upaya untuk meningkatkan Aktivitas Belajar Siswa. Adapun penyusunan rencana tindakan yaitu: a) Membuat Rencana Pelaksanaan Pembelajaran (RPP) disesuaikan dengan penerapan Model Cooperative Learning Tipe STAD Berbantu Media Monopoli. b) Membuat perangkat media monopoli (papan monopoli, kartu kesempatan, kartu dana umum, kartu hak milik perusahaan, lembar pertanyaan beserta kunci jawaban, dadu, uang-uangan, bidak permainan, petunjuk dan aturan permainan). c) Membuat lembar kerja tim sebagai lembar hasil permainan. d) Membuat pre-test dan post-test untuk siklus I, dan soal kemampuan individu sebagai kuis pada siklus II. e) Menyusun lembar observasi untuk pengamatan Aktivitas Belajar Siswa disesuaikan dengan indikator yang akan diamati. f) Membuat rancangan catatan lapangan, membagi siswa secara heterogen ke dalam tim, yaitu tim A, B, C, D, E, F, G, H, dan I. g) Membuat name tag untuk mempermudah pengamatan.

\section{c. Hasil Penelitian Siklus I}

1) Perencanaan Tindakan

Materi yang diajarkan pada siklus I adalah pada Kompetensi Dasar Menyusun Laporan Rekonsiliasi Bank dengan indikator: a).Mengidentifikasi laporan rekening koran 


\section{Jurnal Pendidikan Akuntansi Indonesia, Vol. X, No. 1, Tahun 2012}

bank dan catatan perusahaan serta data pendukung rekonsiliasi bank dan b). Mengidentifikasi selisih antara rekening koran dan catatan perusahaan.

2) Pelaksanaan

Tindakan siklus I dilaksanakan pada hari Rabu, 28 Maret 2012 pukul 9.30 - 14.15 di kelas X Akuntansi 2 SMK Negeri 1 Godean. Siklus I dilakukan sebanyak 1 kali pertemuan (6 x 45 menit) pada Kompetensi Dasar Menyusun Laporan Rekonsiliasi Bank dengan orientasi kegiatan pembelajaran pada Aktitivas Belajar Siswa. Pengamatan Aktivitas Belajar Siswa dilakukan oleh 3 observer ditambah 1 orang sebagai korektor jawaban kuis.

Pembelajaran diawali dengan kegiatan awal yakni guru membuka pelajaran dan apersepsi. Guru menjelaskan model pembelajaran STAD Berbantu Media Monopoli, tidak terlewatkan peneliti membagikan name tag kepada siswa. Guru mengadakan pre-test untuk mengetahui kemampuan dasar siswa dan selanjutnya digunakan untuk skor dasar tiap siswa. Selesai mengerjakan pre-test siswa dikondisikan untuk menempati kursi sesuai dengan pembagian kelompok STAD yang sudah ditentukan sebelumnya.

Pada saat kegiatan inti, guru presentasi kelas dengan teknik tanya jawab dalam menjelaskan Bentuk-Bentuk Rekonsiliasi Bank dan Analisis Selisih Kas Bank. Langkah selanjutnya guru dibantu dengan peneliti mengkondisikan kelas untuk membentuk kelompok besar sesuai dengan denah tempat duduk pada saat diskusi. Korektor mengkoreksi jawaban pre-test siswa, pemain duduk sesuai dengan tim dan kelompok besarnya, observer menyiapkan perangkat permainan monopoli serta membagikan kelengkapan permainan kepada pemain, sedangkan guru menjelaskan aturan permainan. Permainan dilaksanakan selama 2 x 45 menit. Observer dan didampingi oleh guru mengamati diskusi dalam proses pembelajaran. Setelah tugas tim melalui permainan dinyatakan selesai, maka tim menghitung kekayaannya dan menuliskan pada lembar kerja kelompok. Layout kelas di atur kembali seperti semula dan siswa menempati kursi sesuai dengan timnya. Pada saat penyesuaian pengaturan tempat duduk, 2 siswa pengurus kelas sebagai perwalikan kelas yaitu Ika Fitrianingrum dan Ella Elfrida dipanggil oleh OSIS untuk mengikuti rapat.

Guru memberikan kesempatan kepada siswa untuk bertanya sebelum dilaksanakannya kuis individual. Guru memberikan waktu 30 menit kepada siswa untuk mengerjakan kuis individual sebagai post-test. Jawaban dikumpulkan kepada korektor dan dibantu dengan observer mengkoreksi jawaban siswa, selanjutnya untuk dihitung skor peningkatan tim. Sewaktu itu guru mengkondisikan siswa agar lebih kondusif dengan membahas soal post-test. 
Perhitungan selesai, maka didapat 6 tim super, 1 tim hebat, 1 tim baik, dan 1 tim tidak mendapatkan penghargaan. Dalam hal ini semua tim mendapatkan hadiah, namun untuk menentukan tim yang berhak mendapatkan penghargaan maka dilihat dari skor rata-rata peningkatan yang sempurna dan pengumpulan kekayaan terbanyak hasil permainan monopoli.

Pada kegiatan akhir, guru bersama siswa secara klasikal menyimpulkan materi. Guru meyerahkan penghargaan dan motivasi kepada siswa. Guru menutup pelajaran dengan menginformasikan materi yang akan dipelajari pada pertemuan selanjutnya.

3) Pengamatan

Dari hasil pengamatan mengenai Aktivitas Belajar Siswa yang dilakukan observer dan guru kolabolator, maka memperoleh data sebagai berikut:

Tabel 5. Aktivitas Belajar Siswa pada Siklus I

\begin{tabular}{|c|l|c|}
\hline No & \multicolumn{1}{|c|}{ Indikator yang diamati } & $\begin{array}{c}\text { Persentase } \\
\text { Aktivitas Siswa }\end{array}$ \\
\hline 1 & Memperhatikan apa yang disampaikan guru & $68,06 \%$ \\
\hline 2 & $\begin{array}{l}\text { Bertanya dan menyampaikan pendapat pada saat kegiatan belajar } \\
\text { atau diskusi }\end{array}$ & $53,47 \%$ \\
\hline 3 & Bekerja sama dengan teman satu tim & $66,67 \%$ \\
\hline 4 & Membuat perencanaan dan pembagian tugas tim & $67,36 \%$ \\
\hline 5 & Bertanggung jawab terhadap tugas yang telah ditetapkan dalam tim & $70,83 \%$ \\
\hline 6 & $\begin{array}{l}\text { Mendiskusikan masalah yang dihadapi dalam kegiatan belajar } \\
\text { mengajar }\end{array}$ & $74,31 \%$ \\
\hline 7 & Bertukar pendapat antar teman dalam tim & $68,75 \%$ \\
\hline 8 & Memiliki kepedulian terhadap kesulitan sesama anggota tim & $68,06 \%$ \\
\hline 9 & Mengambil keputusan dari pertimbangan anggota & $69,44 \%$ \\
\hline 10 & Mengerjakan kuis dengan kemampuan sendiri & $67,36 \%$ \\
\hline \multicolumn{2}{|c|}{ Rata-Rata Aktivitas Belajar Siswa } & $67,43 \%$ \\
\hline
\end{tabular}

(Sumber: Data primer yang diolah)

4) Refleksi

Penerapan model Cooperative Learning Tipe STAD pada siklus I belum dapat dilaksanakan secara optimal. Hal ini karena siswa belum terbiasa dengan model pembelajaran tersebut, sehingga Aktivitas Belajar Siswa belum muncul secara utuh. Berdasarkan hasil tindakan siklus I, beberapa hal yang perlu ditingkatkan adalah:

a) Petunjuk yang jelas sehingga siswa dapat menyesuaikan diri.

b) Pengendalian guru terhadap jalannya permainan.

c) Kerja sama siswa dalam tim. 
d) Semangat siswa dalam tim, seperti kepedulian dalam kesulitan masing-masing anggota tim.

e) Pemahaman siswa terhadap materi pelajaran dengan kemampuan sendiri.

f) Aktivitas lisan (oral) siswa seperti bertanya dan menyampaikan pendapat pada saat kegiatan belajar atau diskusi dan bertukar pendapat antar teman dalam kelompok.

Dari hasil refleksi terhadap pelaksanaan pembelajaran pada siklus I, maka didapatkan kelemahan - kelemahan dalam pelaksanaan yakni sebagai berikut:

a) Siswa yang tergabung dalam tim hanya memburu untuk menjalankan bidak permainan, tanpa memperhatikan kesulitan yang di alami oleh teman sesama timnya.

b) Waktu dalam menjawab kartu-kartu adalah 1 menit dirasakan terlalu singkat.

c) Perayaan tim ketika berhasil menjawab pertanyaan dan memenangkan permainan terlalu ramai, sehingga mengganggu tim dan kelas lain.

Usaha yang dilakukan untuk perbaikan pada siklus II adalah sebagai berikut:

a) Memberikan petunjuk yang jelas pada siswa terkait konsep pembelajaran.

b) Memotivasi siswa untuk lebih berperan aktif dalam mengerjakan tugas tim.

c) Memberikan pemahaman orientasi permainan bukan sekedar mengumpulkan kekayaan semata, tetapi lebih kepada interaksi edukatif untuk pemahaman materi.

d) Mengatur ulang waktu pengerjaan dalam menjawab kartu.

\section{d. Hasil Penelitian Siklus II}

1) Perencanaan

Sesuai dengan rencana tindakan, desain pembelajaran pada siklus II akan diterapkan pada Kompetensi Dasar Menyusun Laporan Rekonsiliasi Bank untuk memenuhi indikator: a). Menyajikan laporan rekonsiliasi bank, b). Mengidentifikasi data penyesuaian kas di bank dan c). Membukukan data penyesuaian kas di bank. Pelaksanaan siklus II ditargetkan dapat mencapai kriteria keberhasilan yakni Aktivitas Belajar Siswa secara keseluruhan dapat mencapai sekurang-kurangnya sebesar $75 \%$.

2) Pelaksanaan

Tindakan siklus II dilaksanakan pada hari Sabtu, 31 Maret 2012 pukul 8.45 - 13.30 di kelas X Akuntansi 2 SMK Negeri 1 Godean. Siklus II dilakukan sebanyak 1 kali pertemuan (6 x 45 menit) dengan orientasi kegiatan pembelajaran pada Aktitivas Belajar. Pengamatan dilakukan oleh 3 observer, pada siklus II tidak menambah 1 orang sebagai korektor jawaban kuis karena pelaksanaan kuis hanya dilakukan di akhir pertemuan dan pengkoreksian 
jawaban hasil kuis dilakukan oleh observer. Pelaksanaan tindakan diawali dengan kegiatan awal. Guru me-review materi pada pertemuan sebelumnya. Siswa dikondisikan untuk menempati tempat duduk sesuai dengan pengelompokan tim.

Guru mempresentasikan materi Menyajikan laporan rekonsiliasi bank dan Menyusun Ayat Jurnal Penyesuaian. Penyampaian materi dikombinasikan dengan teknik jawab. Siswa senantiasa memperhatikan penjelasan guru dan berinteraksi dalam pembelajaran. Pembelajaran dilanjutkan dengan diskusi kelompok melalui permainan monopoli. Siswa sudah tanggap memposisikan diri menyesuaikan timnya secara tertib. Observer mempersiapkan perlengkapan permainan, sedangkan guru mengingatkan aturan permainan dan menjelaskan aturan tambahan. Siswa sepakat dan paham, selanjutnya observer membagikan soal pra-syarat. Siswa bekerja sama dan berkoordinasi dalam pembagian tugas agar segera menjalankan bidaknya. Permainan dilaksanakan 95 menit. Observer dan guru mengamati diskusi dalam proses pembelajaran. Siswa berorientasi untuk menyelesaikan tugas tim dan mengumpulkan kekayaan melalui perencanaan dan pengambilan keputusan yang baik. Kelas di atur kembali seperti semula dan siswa menduduki kursi sesuai dengan timnya. Guru memberikan kesempatan kepada siswa untuk bertanya sebelum dilaksanakannya kuis individual. Siswa mengerjakan kuis individual dengan waktu 50 menit. Observer mengkoreksi jawaban, selanjutnya dihitung skor peningkatan tim, sedangkan guru mengkondisikan siswa dengan membahas soal kuis individual. Perhitungan selesai, didapatkan 8 tim super dan 1 tim hebat.

Pada kegiatan akhir, guru dan siswa secara klasikal menyimpulkan materi yang telah dipelajari pada siklus II. Guru menyerahkan penghargaan kepada tim D sebagai tim paling super dan mengiringi pembagian hadiah kepada tim lainnya. Guru menyampaikan materi untuk pertemuan selanjutnya dan mengakhiri pembelajaran dengan doa penutup.

3) Pengamatan

Dari pengamatan mengenai Aktivitas Belajar Siswa yang dilakukan observer dan guru kolabolator, siswa sudah bisa menyesuaikan diri dengan model Cooperative Learning Tipe STAD Berbantu Media Monopoli pada pelaksanaan tindakan siklus II. Siswa terbiasa menjalankan tugas masing-masing dan berperan untuk memberikan kontribusi pada pelaksanaan pembelajaran. Data Aktivitas Belajar Siswa dapat dilihat pada tabel berikut: 
Tabel 6. Aktivitas Belajar Siswa pada Siklus II

\begin{tabular}{|c|l|c|}
\hline No & \multicolumn{1}{|c|}{ Indikator yang diamati } & $\begin{array}{c}\text { Persentase } \\
\text { Aktivitas Siswa }\end{array}$ \\
\hline 1 & Memperhatikan apa yang disampaikan guru & $94,44 \%$ \\
\hline 2 & $\begin{array}{l}\text { Bertanya dan menyampaikan pendapat pada saat kegiatan belajar atau } \\
\text { diskusi }\end{array}$ & $81,94 \%$ \\
\hline 3 & Bekerja sama dengan teman satu tim & $88,19 \%$ \\
\hline 4 & Membuat perencanaan dan pembagian tugas tim & $87,50 \%$ \\
\hline 5 & Bertanggung jawab terhadap tugas yang telah ditetapkan dalam tim & $86,81 \%$ \\
\hline 6 & $\begin{array}{l}\text { Mendiskusikan masalah yang dihadapi dalam kegiatan belajar } \\
\text { mengajar }\end{array}$ & $90,97 \%$ \\
\hline 7 & Bertukar pendapat antar teman dalam tim & $84,72 \%$ \\
\hline 8 & Memiliki kepedulian terhadap kesulitan sesama anggota tim & $86,11 \%$ \\
\hline 9 & Mengambil keputusan dari pertimbangan anggota & $86,11 \%$ \\
\hline 10 & Mengerjakan kuis dengan kemampuan sendiri & $93,75 \%$ \\
\hline \multicolumn{2}{|c|}{ Rata-Rata Aktivitas Belajar Siswa } & $88,06 \%$ \\
\hline
\end{tabular}

(Sumber: Data primer yang diolah)

4) Refleksi

Pembelajaran dengan penerapan Model Cooperative Learning Tipe STAD Berbantu Media Monopoli pada siklus II sudah mengalami peningkatan, dilihat dari Aktivitas Belajar Siswa pada siklus II dibandingkan dengan siklus I. Pengelolaan kelas terlaksana secara baik, guru dapat melaksanakan pembelajaran dengan suasana yang kondusif dan siswa sudah dapat mengikuti pembelajaran secara optimal pada pelaksanaan siklus II. Berdasarkan hasil pengamatan Aktivitas Belajar Siswa pada siklus II sudah tampak bahwa siswa lebih aktif dan serius dalam melakukan Aktivitas Belajar.

Dari analisis dan refleksi pada siklus II menunjukkan bahwa indikator keberhasilan siswa sudah dipenuhi dari seluruh indikator yang digunakan dalam penelitian ini. Berdasarkan pengamatan dan diskusi yang dilakukan antara peneliti dan guru pada siklus II, maka upaya perbaikan yang dilakukan secara umum dinyatakan berhasil. Pembahasan materi pada Kompetensi Dasar Menyusun Rekonsiliasi Bank dengan penerapan Model Cooperative Learning Tipe STAD diakhiri pada siklus II.

\section{Pembahasan}

Pelaksanaan Tindakan pada siklus I belum bisa dikatakan optimal. Dilihat dari Aktivitas Belajar Siswa masih ada yang berbicara dengan temannya pada saat guru mempresentasikan materi, siswa masih enggan bertanya dan menyatakan pendapat kepada guru ataupun teman timnya. Pada waktu pelaksanaan diskusi melalui permainan, siswa kurang bekerja sama, masih mengerjakan tanggung jawab tugas sendiri tanpa mempedulikan 
kesulitan antar anggota tim, namun pada saat pengerjaan soal post-test terlihat beberapa siswa yang mendiskusikan jawabannya.

Evaluasi pada siklus I dilakukan untuk perbaikan pada pelaksanaan tindakan siklus II. Perbaikan yang dilakukan adalah memberikan petunjuk yang jelas kepada siswa, memotivasi siswa untuk lebih berperan aktif dalam mengerjakan tugas tim, memberikan pemahaman orientasi permainan, dan mengatur ulang waktu pengerjaan tugas tim. Melalui perbaikan Aktivitas Belajar Siswa Kelas X Akuntansi 2 SMK Negeri 1 Godean mengalami peningkatan dari siklus I ke siklus II sebesar 20,63\% yaitu dari 67,43\% menjadi 88,06\% . Data mengenai peningkatan Aktivitas Belajar Siswa dengan penerapan Model Cooperative Learning Tipe STAD Berbantu Media Monopoli pada Kompetensi Dasar Menyusun Laporan Rekonsiliasi Bank pada Kelas X Akuntansi 2 dapat dilihat pada tabel berikut ini:

Tabel 7. Aktivitas Belajar Siswa Kelas X Akuntansi 2

\begin{tabular}{|c|c|c|c|c|}
\hline No & Indikator yang diamati & Siklus I & Siklus II & $\begin{array}{l}\text { Pening- } \\
\text { Katan }\end{array}$ \\
\hline 1 & Memperhatikan apa yang disampaikan guru & $68,06 \%$ & $94,44 \%$ & $26,38 \%$ \\
\hline 2 & $\begin{array}{l}\text { Bertanya dan menyampaikan pendapat pada saat } \\
\text { kegiatan belajar atau diskusi }\end{array}$ & $53,47 \%$ & $81,94 \%$ & $28,47 \%$ \\
\hline 3 & Bekerja sama dengan teman satu tim & $66,67 \%$ & $88,19 \%$ & $21,52 \%$ \\
\hline 4 & Membuat perencanaan dan pembagian tugas tim & $67,36 \%$ & $87,50 \%$ & $20,14 \%$ \\
\hline 5 & $\begin{array}{l}\text { Bertanggung jawab terhadap tugas yang telah } \\
\text { ditetapkan dalam tim }\end{array}$ & $70,83 \%$ & $86,81 \%$ & $15,98 \%$ \\
\hline 6 & $\begin{array}{l}\text { Mendiskusikan masalah yang dihadapi dalam } \\
\text { kegiatan belajar mengajar }\end{array}$ & $74,31 \%$ & $90,97 \%$ & $16,66 \%$ \\
\hline 7 & Bertukar pendapat antar teman dalam tim & $68,75 \%$ & $84,72 \%$ & $15,97 \%$ \\
\hline 8 & $\begin{array}{l}\text { Memiliki kepedulian terhadap kesulitan sesama } \\
\text { anggota tim }\end{array}$ & $68,06 \%$ & $86,11 \%$ & $18,05 \%$ \\
\hline 9 & Mengambil keputusan dari pertimbangan anggota & $69,44 \%$ & $86,11 \%$ & $16,67 \%$ \\
\hline 10 & Mengerjakan kuis dengan kemampuan sendiri & $67,36 \%$ & $93,75 \%$ & $26,39 \%$ \\
\hline & Rata-Rata Aktivitas Belajar & $67,43 \%$ & $88,06 \%$ & $20,63 \%$ \\
\hline
\end{tabular}

(Sumber: Data primer yang diolah)

Dari tabel diatas, Aktivitas Belajar Siswa dengan penerapan Model Cooperative Learning Tipe STAD Berbantu Media Monopoli pada Kompetensi Dasar Menyusun Laporan Rekonsiliasi Bank pada Kelas X Akuntansi 2 mengalami peningkatan, data peningkatan dapat dilihat melalui grafik sebagai berikut: 
Aktivitas Belajar Siswa Siklus I dan Siklus II

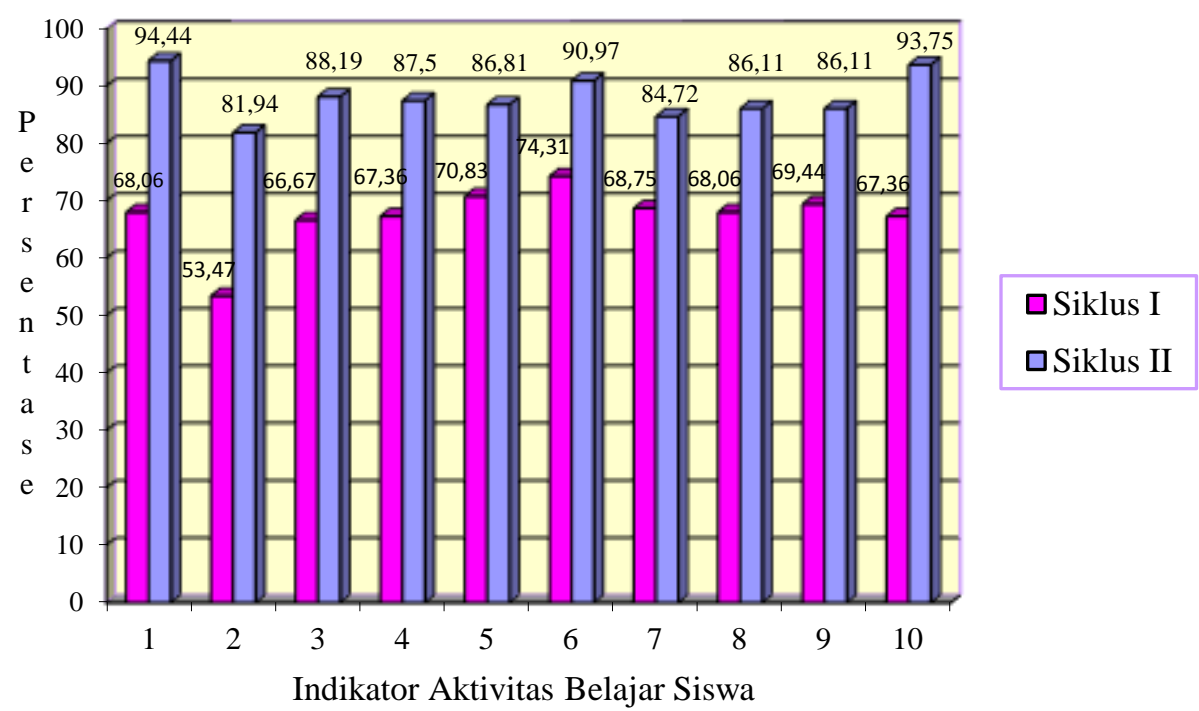

Gambar 2. Peningkatan Aktivitas Belajar Siswa pada Siklus I dan Siklus II (Sumber: Data primer yang diolah)

Berdasarkan data diatas, Aktivitas Belajar Siswa mengalami peningkatan pada siklus II. Siswa yang memperhatikan apa yang disampaikan guru sebesar 68,06\% pada siklus I menjadi 94,44\% pada siklus II, siswa yang bertanya dan menyampaikan pendapat pada saat kegiatan belajar atau diskusi sebesar $53,47 \%$ pada siklus I menjadi $81,94 \%$ pada siklus II, siswa yang bekerja sama dengan teman satu tim sebesar $66,67 \%$ pada siklus I menjadi $88,19 \%$ pada siklus II, siswa yang membuat perencanaan dan pembagian tugas tim sebesar $67,36 \%$ pada siklus I menjadi $87,50 \%$ pada siklus II, siswa yang bertanggung jawab tehadap tugas yang telah ditetapkan dalam tim sebesar $70,83 \%$ pada siklus I menjadi $86,81 \%$ pada siklus II, siswa yang mendiskusikan masalah yang dihadapi dalam kegiatan belajar mengajar sebesar $74,31 \%$ pada siklus I menjadi $90,97 \%$ pada siklus II, siswa yang bertukar pendapat antar teman dalam tim sebesar $68,75 \%$ pada siklus I menjadi $84,72 \%$ pada siklus II, siswa yang memiliki kepedulian terhadap kesulitan sesama anggota tim sebesar 68,06\% pada siklus I menjadi $86,11 \%$ pada siklus II, siswa yang mengambil keputusan dari pertimbangan anggota sebesar $69,44 \%$ pada siklus I menjadi $86,11 \%$ pada siklus II, siswa yang mengerjakan kuis dengan kemampuan sendiri sebesar 67,36\% pada siklus I menjadi 93,75\% pada siklus II.

Hasil penelitian ini menunjukkan bahwa terdapat peningkatan Aktivitas Belajar dengan penerapan model Cooperative Learning Tipe STAD Berbantu Media Monopoli. Hal ini ditunjukkan pada Aktivitas siswa sebelum menggunakan model Cooperative Learning 
Tipe STAD Berbantu Media Monopoli sebesar 39,31\%, pada pelaksanaan tindakan siklus I Aktivitas Belajar meningkat menjadi 67,43\%, dan selanjutnya pada pelaksanaan tindakan siklus II meningkat menjadi 88,06\%. Peningkatan tersebut sudah mencapai indikator keberhasilan yang diharapkan yaitu $75 \%$ dari jumlah siswa dalam satu kelas telah aktif selama pembelajaran menggunakan model Cooperative Learning Tipe STAD.

Hasil penelitian ini membuktikan hipotesis tindakan bahwa Penerapan Model Cooperative Learning Tipe Student Teams Achievement Division (STAD) Berbantu Media Monopoli dapat Meningkatkan Aktivitas Belajar Akuntansi Siswa Kelas X Akuntansi 2 SMK Negeri 1 Godean Tahun Ajaran 2011/2012. Hasil penelitian ini sesuai dengan teori yang disampaikan Isjoni (2010: 74) bahwa pembelajaran kooperatif tipe STAD merupakan salah satu tipe kooperatif yang menekankan pembelajaran pada adanya aktivitas dan interaksi diantara siswa untuk saling memotivasi dan saling membantu dalam menguasai materi pelajaran guna mencapai prestasi yang maksimal.

Model Cooperative Learning Tipe STAD menekankan pengelompokan secara heterogen sehingga mengupayakan siswa untuk mengajarkan sesuatu dengan baik kepada siswa lainnya pada waktu yang bersamaan. Adanya diskusi akan tercipta interaksi edukatif, serta dengan penghargaan dalam metode ini dapat meningkatkan peran serta dan aktivitas siswa karena masing-masing tim termotivasi untuk mendapatkan penghargaan. Dukungan media pembelajaran monopoli yang dapat membantu siswa dalam membangkitkan minat dan motivasi siswa yang selanjutnya siswa akan melakukan Aktivitas Belajar.

Berdasarkan hasil wawancara yang dilakukan kepada guru dan siswa setelah tindakan, guru berpendapat bahwa model Cooperative Learning Tipe STAD Berbantu Media Monopoli dapat meningkatkan Aktivitas Belajar Siswa karena membuat siswa dinamis dalam belajar. Tanggapan beberapa siswa bahwa mereka menjadi lebih mudah memahami materi yang diberikan karena disajikan melalui permainan dan diselesaikan bersama teman timnya yang saling membantu.

\section{Penutup}

Penerapan Model Cooperative Learning Tipe Student Teams Achievement Division (STAD) Berbantu Media Monopoli dapat meningkatkan Aktivitas Belajar Akuntansi pada kompetensi dasar Menyusun Rekonsiliasi Bank Siswa Kelas X Akuntansi 2 SMK Negeri 1 Godean Tahun Ajaran 2011/2012. Aktivitas Belajar Siswa secara umum mengalami peningkatan pada siklus I dan siklus II. Sebelum menggunakan Model Cooperative Learning Tipe Student Teams Achievement Division (STAD) Berbantu Media Monopoli, Aktivitas 
Belajar siswa hanya 39,31\%, setelah menggunakan Model Cooperative Learning Tipe Student Teams Achievement Division (STAD) Berbantu Media Monopoli pada siklus I Aktivitas Belajar Siswa meningkat sebesar 67,43\% dan meningkat lagi pada siklus II menjadi $88,06 \%$.

\section{E. Daftar Pustaka}

Apriliana Rejeki. (2010). Akhir dari Inovasi Pembelajaran. Diakses dari http://edukasi.kompasiana.com/2010/12/27/akhir-dari-inovasi-pembelajaran/ pada tanggal 7 Februari 2012 pukul 8:38 WIB.

Arief S.Sadiman, dkk. (2011). Media Pendidikan Pengertian, Pengembangan, dan Pemanfaatannya. Jakarta: Raja Grafindo Persada.

Dian Alimatussholikha HS. (2008). Permainan Monopoli dan Ular Tangga Sebagai Media Latihan Soal Fisika Pokok Bahasan Gaya Kelas Viii Di MTsN Yogyakarta I. Skripsi. Yogyakarta: Pendidikan Fisika dan Teknologi SAINSTEK. UIN Sunan Kalijaga.

Dodo Suwanda. (2008). Model Pembelajaran Monopoly Pakem. Diakses dari http://dossuwanda.wordpress.com/2008/03/10/model-pembelajaran-monopoly-pakem/ pada tanggal 8 Oktober 2011 pukul 9:25 WIB.

E.Mulyasa. (2006). Kurikulum Tingkat Satuan Pendidikan. Bandung: Remaja Rosdakarya.

Isjoni. (2010). Pembelajaran Kooperatif Meningkatkan Kecerdasan Komunikasi Antar Peserta Didik. Yogyakarta: Pustaka Pelajar.

Mushlihin al-Hafizh. (2011). Model Pembelajaran Cooperative Learning. Diakses dari http://www.surgamakalah.com/2011/07/model-pembelajaran-cooperatif-learning.html pada tanggal 8 Februari 2012 pukul 23:09 WIB.

Oemar Hamalik. (2005). Proses Belajar Mengajar. Jakarta: Bumi Aksara.

Sadan Hasan. (2011). Meningkatkan Prestasi Belajar Matematika Siswa Kelas VIIII SMP Negeri 1 Batuatas pada Pokok Bahasan Sistem Persamaan Linear Dua Peubah Melalui Model Pembelajaran Kooperatif Tipe NHT. Diakses dari http://goesbas.blogspot.com/2011/05/meningkatkan-prestasi-belajar.html pada tanggal 4 Februari 2012 pukul 13:36 WIB.

Slavin.E. Robert. (2010). Cooperative Learning. Teori, Riset, dan Praktik. Bandung: Nusa Media.

Suci Rohmawati. (2011). Peningkatan Hasil Belajar Akuntansi Pada Kompetensi Mengelola Dana Kas Kecil Melalui Penggunaan Model Pembelajaran Kooperatif Tipe Student Teams Achievement Divisions Siswa Kelas X Akuntansi 3 SMK Negeri 1 Wonosari. Tahun Ajaran 2010/2011. Skripsi. Yogyakarta: Pendidikan Akuntansi FISE UNY.

Sugiyono. (2009). Metode Penelitian Pendidikan. Bandung: Alfabeta.

Suharsimi Arikunto. (2011). Penelitian Tindakan Kelas. Jakarta: Bumi Aksara. 
Sunenti. (2011). Implementasi Model Pembelajaran Kooperatif Pendekatan Struktural Tipe Numbered Head Together Untuk Meningkatkan Aktivitas dan Hasil Belajar Pada Kompetensi Kas Bank Siswa Kelas X Akuntansi 3 SMK Negeri 1 Godean Tahun Ajaran 2010/2011. Skripsi. Yogyakarta: Pendidikan Akuntansi FISE UNY.

Sriyono. (2012). Definisi Aktivitas Siswa. Diakses dari http://id.shvoong.com/socialsciences/education/2253227-definisi-aktivitas-siswa/ pada tanggal 11 Januari 2012 pukul 15:36 WIB.

Ummu Rubiyatun. (2011). Implementasi Model Cooperative Learning Tipe Student Teams Achievement Division (STAD) Untuk Meningkatkan Aktivitas Belajar Siswa Kelas X AK 3 SMK Batik Perbaik Purworejo Tahun Ajaran 2010/2011. Skripsi. Yogyakarta: Pendidikan Akuntansi FISE UNY.

Wina Sanjaya. (2009). Strategi Pembelajaran Berorientasi Standar Proses Pendidikan. Jakarta: Kencana Prenada Media Group. . (2011). Penelitian Tindakan Kelas. Jakarta: Kencana Prenada Media Group.

Yanda Nur. (2011). “Ketakjuban” Saya Pada Dunia Pendidikan Kita. Diakses dari http://www.yandanur.web.id/2011/06/ketakjuban-saya-pada-dunia-pendidikan.html pada tanggal 8 Februari 2012 pukul 23:43 WIB. 